Published in final edited form as:

Methods Mol Biol. 2009 ; 482: 215-232. doi:10.1007/978-1-59745-060-7_14.

\title{
Isolation and Culture of Epithelial Stem Cells
}

\author{
Jonathan A. Nowak and Elaine Fuchs
}

\begin{abstract}
In the skin, epithelial stem cells in the hair follicle contribute not only to the generation of a new hair follicle with each hair cycle, but also to the repair of the epidermis during wound healing. When these stem cells are isolated and expanded in culture, they can give rise to hair follicles, sebaceous glands, and epidermis when combined with dermis and grafted back onto Nude mice. In this chapter, we provide a method for isolating hair follicle epithelial stem cells from the skin of adult mice using immunofluorescent labeling to allow for the specific purification of epithelial stem cells by fluorescence-activated cell sorting (FACS). Notably, this method relies exclusively on cell surface markers, making it suitable for use with any strain of mouse and at various stages of the hair cycle. We also provide a detailed protocol for culturing epithelial stem cells isolated by FACS, allowing for analysis using a wide variety of culture assays. Additionally, we provide notes on using cultured cells for specific applications, such as viral manipulation and grafting. These techniques should be useful for directly evaluating stem cell function in normal mice and in mice with skin defects.
\end{abstract}

\section{Keywords}

Epithelial stem cells; skin stem cells; hair follicles; bulge stem cells

\section{Introduction}

The skin is a tissue which undergoes continuous self-renewal throughout the lifetime of an organism and also has an extensive ability to repair wounds. For these reasons, a stem cell population has long been suspected to exist within the epithelial compartment of the skin. Numerous lines of evidence, including grafting, lineage tracing and pulse-chase experiments to measure cell cycle times, have suggested that the bulge region of the hair follicle acts as a reservoir for skin epithelial stem cells (1-3).

The bulge is the lowest permanent epithelial portion of the hair follicle. At the start of each hair cycle, bulge stem cells migrate downward to regenerate the bulk of the hair follicle and produce a new hair (anagen phase). In mouse backskin, at the end of each hair cycle, the bulge progeny degenerate (catagen phase) to form a thin epithelial strand. When the strand regresses, it drags the dermal papilla (DP) cells of the hair follicle upward to rest beneath the bulge (telogen phase). After a variable period of time in telogen, bulge cells become activated and start the hair cycle anew. In addition to fueling the normal hair cycle, bulge stem cells are also able to move upwards to repair the epidermis and sebaceous glands during wound healing, and thus these cells are referred to as multipotent stem cells $(4,5)$.

Functional evaluation of bulge stem cell character has been greatly accelerated by recent advances in isolating pure populations of viable bulge cells. Several techniques have been developed for the isolation of bulge cells by fluorescence-activated cell sorting (FACS). Typically, these methods have relied upon transgenic mice expressing fluorescent proteins that preferentially label bulge cells based on their slow-cycling nature or specific promoter activity $(4,5)$. Such methods are often best suited for isolating bulge cells at the telogen stage, a time at which most of the hair follicle is missing. However, a combination of antibodies against the 
cell surface proteins CD34 and $\alpha 6$-integrin can also be used to identify distinct populations of cells by FACS, which are greatly enriched for bulge stem cells $(6,7)$.

When these FACS-isolated bulge cell populations are placed in culture, they give rise to colonies that display stem cell properties, including long-term self-renewal, and when the progeny of an individual FACS-purified bulge cells are grafted onto Nude mice, the cells are able to regenerate hair, interfollicular epidermis, and sebaceous glands, reflecting their multipotency. The $\alpha 6 / \mathrm{CD} 34$ bulge cell isolation technique is particularly advantageous because it can be performed in the absence of fluorescent transgenic reporters, making it suitable to use with any mouse strain (see Note 1). Additionally, this technique can be used to isolate bulge cells from both anagen and telogen stage hair follicles, and, furthermore, it allows for the division of the bulge cell population into two distinct subpopulations based on differential $\alpha 6$ integrin expression. Culture conditions that have been optimized for the propagation of sorted bulge cells allow for the functional assessment of bulge stem cell properties using a variety of assays $(7,8)$.

\section{Materials}

\subsection{Cell Culture}

1. Dulbecco's modified Eagle's medium/Ham's F-12 Nutrient Medium (3:1 Mix) without Calcium (Gibco Invitrogen, special order custom powdered media, Cat. \#905010EA)

2. Dulbecco's modified Eagle's medium (Gibco Invitrogen)

3. F-12 Nutrient Mixture (Ham's) (Gibco Invitrogen)

4. Fetal bovine serum (US characterized or defined) (Hyclone)

5. Bovine calf serum (defined, supplemented) (Hyclone)

6. Penicillin-streptomycin (Gibco Invitrogen)

7. Sodium bicarbonate (Invitrogen)

8. L-glutamine (Invitrogen)

9. Hydrocortisone (Calbiochem)

10. Cholera toxin (MP Biomedicals)

11. Insulin (Sigma)

12. $\mathrm{T}_{3}\left(3,3^{\prime}, 5\right.$-triiodo-L-thyronine) (Sigma)

13. Chelex (100 resin, sodium, 200-400 dry mesh, $75-150 \mathrm{~mm}$ wet bead) (Bio-Rad)

14. Trypsin-EDTA $0.25 \%(1 \times)$ (Gibco Invitrogen)

15. Antibiotic-antimycotic (100x) (Gibco Invitrogen)

16. Calcium chloride $0.06 \mathrm{M}$ (Cascade Biologics)

17. Mitomycin $\mathrm{C}$ (Roche)

18. Phosphate-buffered saline

19. Concentrated $\mathrm{HCl}$ and $\mathrm{NaOH}$ solutions for $\mathrm{pH}$ adjustment and preparing stock solutions

20. $95 \%$ Ethanol 
21. Glass distilled $\mathrm{H}_{2} \mathrm{O}$; Milli-Q tissue culture grade $\mathrm{H}_{2} \mathrm{O}$ if glass distilled is not available

22. Compressed $\mathrm{CO}_{2}$ source.

2.2. FACS

1. Phycoerythrin-conjugated rat anti-human CD49f [integrin $\alpha_{6}$ chain] (clone GoH3) (BD Pharmingen)

2. Biotin-conjugated rat anti-mouse CD34 (clone RAM34) (eBioscience)

3. Streptavidin-allophycocyanin conjugate (BD Pharmingen)

4. Propidium iodide (Sigma).

\subsection{Instruments and Supplies}

1. 4 inch dissecting forceps (Biomedical Research Instruments)

2. 4 inch Iris Scissors (Miltex)

3. \#21 blade steel scalpel (Fisher Scientific)

4. Dissection pad and pan (Fisher Scientific)

5. $20 \mathrm{~g}$ Syringe needles, or equivalent (Becton Dickinson)

6. Electric Shaver (Oster Professional Products)

7. Reichert Brightline Hemocytometer (Hausser Scientific)

8. Trypan blue solution $(0.4 \%)$ (Sigma)

9. $50 \mathrm{~mL}$ conical tubes (BD Falcon)

10. $40 \mu \mathrm{M}$ nylon cell strainers (BD Falcon)

11. $70 \mu \mathrm{M}$ nylon cell strainers (BD Falcon)

12. $5 \mathrm{~mL}$ round-bottom cap tubes (BD Falcon)

13. $5 \mathrm{~mL}$ cell strainer round-bottom cap tubes (BD Falcon)

14. Tissue culture dish, $100 \times 20 \mathrm{mM}$ (BD Falcon)

15. Tissue culture plate, 24-well flat bottom (BD Falcon)

16. Millipore Millex $0.22 \mu \mathrm{M}$ PVDF syringe filter (Fisher)

17. Nalgene MF75 Disposable Sterile Filtration Unit, or equivalent (Fisher Scientific)

18. 4-color Flow Cytometer; BD FACSCalibur or equivalent (BD Biosciences)

\subsection{Mice}

1. Any standard laboratory mouse strain, $\mathrm{d} 20$ or older.

\subsection{Feeder Cells}

1. Swiss $3 \mathrm{~T} 3$ cells or equivalent (ATCC).

\subsection{Preparation of Epithelial Media Components}

\subsubsection{Preparation of Stock Media Additives (see Note 2)}

1. $5 \mathrm{mg} / \mathrm{ml}$ insulin: Dissolve in $0.1 \mathrm{NHCl}$, store in $10 \mathrm{ml}$ aliquots at $4^{\circ} \mathrm{C}$. 
2. $5 \mathrm{mg} / \mathrm{ml}$ transferrin: Dissolve in sterile PBS, store in $10 \mathrm{ml}$ aliquots at $-20^{\circ} \mathrm{C}$.

3. $2 \times 10^{-8} M T_{3}\left(3,3^{\prime}, 5\right.$-Triiodo-L-thyronine $)$ : Dissolve in $0.02 \mathrm{~N} \mathrm{NaOH}$ to produce initial stock solution of $2 \times 10^{-4} \mathrm{M}$ of $\mathrm{T}_{3}$. Perform serial solutions in PBS to produce $10 \mathrm{ml}$ of $2 \times 10-8 \mathrm{M} \mathrm{T}_{3}$ aliquots. Store stocks from each step at $-20^{\circ} \mathrm{C}$.

4. 100× Additive Cocktail: Mix $20 \mathrm{ml}$ of $5 \mathrm{mg} / \mathrm{ml}$ insulin, $20 \mathrm{ml}$ of $5 \mathrm{mg} / \mathrm{ml}$ transferrin, $20 \mathrm{ml}$ of $2 \times 10^{-8} \mathrm{M}$ of $\mathrm{T}_{3}$, and $140 \mathrm{ml}$ sterile PBS. Sterilize with Nalgene filter and store in $37.5 \mathrm{ml}$ aliquots at $-20^{\circ} \mathrm{C}$.

5. $4 \mathrm{mg} / \mathrm{ml}$ Hydrocortisone: Dissolve one vial in $95 \%$ ethanol to produce desired concentration. Filter sterilize and store in $1 \mathrm{ml}$ aliquots at $-20^{\circ} \mathrm{C}$.

6. $10^{-6} \mathrm{M}$ Cholera toxin: Dissolve one vial in glass distilled water to produce desired concentration. Filter sterilize and store in $1 \mathrm{ml}$ aliquots at $4^{\circ} \mathrm{C}$.

2.6.2. Preparation of Chelated Fetal Bovine Serum-Epithelial cells are exquisitely sensitive to calcium, and it is essential to carefully control the calcium levels to which cells are exposed at all times. In order to prepare media with a defined calcium concentration, it is necessary first to remove residual calcium normally present in fetal bovine serum via chelation. The protocol listed below generates approximately $1 \mathrm{~L}$ of calcium- free fetal bovine serum, which is sufficient for preparing the epidermal media in the next section as well as for use in preparing FACS staining buffer.

1. Add $400 \mathrm{~g}$ of dry Chelex to a $4 \mathrm{~L}$ beaker with a stir bar. Add glass-distilled $\mathrm{H}_{2} \mathrm{O}$ to a total volume of $4 \mathrm{~L}$. Cover and stir continuously.

2. Adjust $\mathrm{pH}$ to 7.4 using $10 \mathrm{NHCl}$. Stir for $20 \mathrm{~min}$, readjust $\mathrm{pH}$ with $10 \mathrm{~N} \mathrm{HCl}$, and repeat as needed until $\mathrm{pH}$ remains stable for more than $20 \mathrm{~min}$.

3. Place the beaker at $4^{\circ} \mathrm{C}$ overnight to allow the Chelex to form a compact pellet.

1. Carefully decant $\mathrm{H}_{2} \mathrm{O}$. Add fresh $\mathrm{H}_{2} \mathrm{O}$ to $4 \mathrm{~L}$.

2. Adjust the $\mathrm{pH}$ to 7.4 as in Day 1 .

3. Place the beaker at $4^{\circ} \mathrm{Cfor} 1$ hour to allow the Chelex to form a compact pellet.

4. Carefully decant $\mathrm{H}_{2} \mathrm{O}$.

5. Slowly add two $500 \mathrm{ml}$ bottles of characterized or defined fetal bovine serum to the Chelex.

6. Stir slowly at $4^{\circ} \mathrm{C}$ for $1 \mathrm{hr}$, with a speed set to minimize bubbles.

7. Place the beaker at $4^{\circ} \mathrm{C}$ for 1 hour to allow the Chelex to form a compact pellet.

8. Decant the serum into a $1 \mathrm{~L}$ glass bottle and filter the serum through a Nalgene bottle top filter under sterile conditions.

9. Store unused $\mathrm{FBS}$ at $-20^{\circ} \mathrm{C}$ or use immediately to make $\mathrm{E}$ media without calcium.

\subsubsection{Preparation of E Media Without Calcium for Epidermal Cells (see Note 3)}

1. In a $6 \mathrm{~L}$ Erlenmeyer flask, combine six packets of Gibco Invitrogen customized DMEM:F12 (3:1) without calcium with glass distilled $\mathrm{H}_{2} \mathrm{O}$ to reach a final volume of $5.5 \mathrm{~L}$ ( see Note 4).

2. Add $18.42 \mathrm{~g}$ of sodium bicarbonate, $2.85 \mathrm{~g}$ of L-glutamine, and $60 \mathrm{~mL}$ of $100 \mathrm{x}$ penicillin-streptomycin solution. 
3. Adjust $\mathrm{pH}$ to 7.2 using $10 \mathrm{~N} \mathrm{HCl}$ and adjust the volume to $6 \mathrm{~L}$ with $\mathrm{H}_{2} \mathrm{O}$.

4. Apply compressed $\mathrm{CO}_{2}$ to the media for $15 \mathrm{~min}$. The media should reach an amber color.

5. Combine stock additives with chelated FBS prepared in 3.1 .2 by adding $75 \mathrm{ml}$ of $100 \times$ cocktail, $750 \mu 1$ cholera toxin, and $750 \mu 1$ hydrocortisone to $1 \mathrm{~L}$ of chelated FBS.

6. Produce final $15 \%$ FBS media in $1 \mathrm{~L}$ batches by combining $850 \mathrm{ml}$ of the DMEM:F12 media base from step 4 with $150 \mathrm{ml}$ of the supplemented chelated FBS from step 5 and sterilize using a Nalgene bottle top filter.

7. Media can be stored in 250 or $500 \mathrm{~mL}$ bottles at $-20^{\circ} \mathrm{C}$.

8. Note that calcium must be added to media used for cell culture, but must be omitted from media used in the cell preparation for FACS.

\subsection{Preparation of F Media for $3 T 3$ Feeder Cells}

1. In a $4 \mathrm{~L}$ Erlenmeyer flask, combine three $1 \mathrm{~L}$ packets of Dulbecco's modified Eagle's medium and one $1 \mathrm{~L}$ packet of F-12 Nutrient Mixture (Ham's) with glass distilled $\mathrm{H}_{2} \mathrm{O}$ to reach a final volume of $3.5 \mathrm{~L}$.

2. Add $12.28 \mathrm{~g}$ of sodium bicarbonate, $1.9 \mathrm{~g}$ of L-glutamine, and $40 \mathrm{~mL}$ of $100 \times$ penicillin-streptomycin solution.

3. Adjust $\mathrm{pH}$ of medium using $1 \mathrm{~N} \mathrm{NaOH}$ or $1 \mathrm{~N} \mathrm{HCl}$ to 7.20 and adjust volume to $4 \mathrm{~L}$ with $\mathrm{H}_{2} \mathrm{O}$ (see Note 6).

4. Filter sterilize using a Nalgene bottle top filter.

5. Media can be stored in $500 \mathrm{~mL}$ bottles at $-20^{\circ} \mathrm{C}$.

6. Add bovine calf serum to a final concentration of $10 \%$ to make complete media.

\section{Methods}

\subsection{Propagation of $3 \mathrm{~T} 3$ Feeder Cells}

Healthy feeder cells are a critical determinant of success in culturing epithelial cells $(8,9)$. Feeder cells can be produced by treating $3 \mathrm{~T} 3$ cells with mitomycin $\mathrm{C}$ to permanently arrest cell division 220 Nowak and Fuchs without killing cells. Treated cells are then pre-plated as a monolayer before co-culturing with epithelial stem cells (10). Swiss 3T3 is not a cloned cell line, and certain precautions should be taken when growing them to ensure that they maintain optimal properties for supporting epithelial stem cell growth (see Note 5).

1. $3 \mathrm{~T} 3$ cell lines are conveniently propagated in $100 \mathrm{~mm}$ tissue culture dishes with 10 $\mathrm{mL}$ of $\mathrm{F}$ media per plate. Do not allow actively growing cells to become confluent before passaging.

2. Always feed $3 \mathrm{~T} 3$ cells the day before transferring.

3. When plates reach $80 \%$ confluence, trypsinize cells, and split at a 1:10-1:15 ratio.

\subsection{Mitomycin C Treatment of $3 \mathrm{~T} 3$ Cells}

1. Dissolve mitomycin $\mathrm{C}$ in sterile PBS to produce a $0.4 \mathrm{mg} / \mathrm{mL}$ stock. Mix well and sterile filter using $0.22 \mu \mathrm{M}$ syringe filter. Store protected from light at $4^{\circ} \mathrm{C}$.

2. Remove media from $100 \mathrm{~mm}$ plates of confluent $3 \mathrm{~T} 3$ cells. Add $5 \mathrm{~mL}$ of fresh F media per $100 \mathrm{~mm}$ plate. 
3. Add $100 \mu \mathrm{L}$ of mitomycin $\mathrm{C}$ stock solution to each $100 \mathrm{~mm}$ plate.

4. Incubate plates for $2 \mathrm{hr}$.

5. Wash cells two times with $5 \mathrm{~mL}$ of PBS per plate.

6. Add fresh $\mathrm{F}$ media to plates and return to incubator. Cells treated with mitomycin $\mathrm{C}$ will remain viable for several weeks, provided they are given fresh media one to two times per week.

\subsection{Preparation of Single Cell Suspension from Adult Epidermis}

The preparation of a high quality, single cell suspension is the most essential component of successful FACS. Careful shaving and dissection to minimize the amount of non-epidermal tissue subject to enzymatic dissociation helps to ensure a clean, high yield preparation of epidermal cells. Handling cells gently and keeping suspensions on ice at all times helps to maintain cell viability. Practicing sterile technique will help to minimize the chance of contamination if cells are to be used for culture experiments.

1. Kill mice following standard laboratory protocol and use the electric shaver to remove all hair from body of an adult mouse, excluding the head and limbs. Shave as close to the skin as possible while being careful to avoid nicks.

2. Wash skin with $70 \%$ ethanol to remove hair residue and reduce the chance of microbial contamination. Blot dry.

3. Use forceps and scissors to make a full length dorsal midline incision from the head to the tail. Starting from the dorsal incision, make two circumferential incisions-one just behind the forepaws and the other just before the hindpaws. Use the forceps to carefully peel off the skin in one piece from the mouse.

4. Place the skin hair side down on the dissecting pad and use the needles to pin down two adjacent sides of the skin.

5. Using the scalpel, gently scrape away the fat and blood vessels covering the dermis until the dermis is clearly and uniformly exposed. Note that the dermis has a much duller appearance than fat, which is shiny and reflective (see Note 7).

6. Fill a $100 \mathrm{~mm}$ TC dish with $10 \mathrm{~mL}$ of PBS and carefully float the skin, dermis side down, on the PBS. Ensure that the skin is flat and unfolded and that the epidermal side remains dry and unsubmerged.

7. Once all skins have been processed, aspirate the PBS from each dish and add $10 \mathrm{~mL}$ of $0.25 \%$ trypsin per dish, making sure that the skin is freely floating with an unsubmerged epidermis.

8. Incubate skins overnight at $4^{\circ} \mathrm{C}$.

9. The next day, use the scalpel and forceps to separate the epidermis from the dermis. Hold the skin in one corner with forceps while gently scraping along the top to remove the epidermis, which will easily peel off in small chunks. Note that the dermis is very durable and cannot be easily disrupted by scraping.

10. Remove the dermis from the dish and use the scalpel and forceps to briefly mince the largest pieces of tissue.

11. Pour the trypsin and epidermis mixture into a $50 \mathrm{ml}$ Falcon tube.

12. Repeatedly pipette up and down with a $10 \mathrm{ml}$ pipette to triturate the tissue. It may be necessary to tap the end of the pipette on the bottom of the tube to pick up all of the tissue. Continue until the mixture can be easily pipetted without tapping. 
13. Place a $70 \mu$ Mcell strainer on top of a new $50 \mathrm{~mL}$ Falcon tube and pass the mixture over the strainer. Wash the strainer with $5 \mathrm{~mL}$ of cold $\mathrm{E}$ no calcium media to collect residual cells, and inactivate the trypsin.

14. Pass the resulting cell suspension over a $40 \mu \mathrm{m}$ cell strainer and collect in a new Falcon tube. Add cold E no calcium media to bring the final volume up to $25 \mathrm{~mL}$. Place the suspension on ice until all skins have been processed.

15. Spin tubes for $10 \mathrm{~min}$ at $250 \mathrm{~g}$ to pellet cells. After the spin, it is normal for the supernatants to be cloudy because they contain dead cells and other debris which does not pellet efficiently. Carefully aspirate supernatants without disturbing the cell pellet.

16. Make fresh staining buffer for use in subsequent steps by adding $1 \mathrm{~mL}$ of chelated fetal bovine serum prepared in 3.1.2 to $49 \mathrm{~mL}$ of sterile PBS. Keep on ice.

17. Resuspend each pellet in $5 \mathrm{~mL}$ of staining buffer. Spin again for $5 \mathrm{~min}$ at $250 \mathrm{~g}$ and pour off supernatant (see Note 8 ).

18. Resuspend cells from both pellets in $1 \mathrm{~mL}$ total of staining buffer.

19. Strain the cells once more by passing through the cap of a $5 \mathrm{~mL}$ cell strainer cap FACS tube (see Note 9).

\subsection{Staining and FACS Isolation of Epithelial Stem Cells}

1. From the $1 \mathrm{~mL}$ cell suspension prepared in 3.4 , remove $4 \_50 \mu \mathrm{L}$ aliquots and place each in a separate FACS tube. Add $250 \mu \mathrm{L}$ of staining buffer to each $50 \mu \mathrm{L}$ aliquot to match the volumes listed in Table 14.1 and label samples as indicated (see Note 10).

2. Add the amount of primary antibody indicated in Table 14.1 to the appropriate tubes. Gently mix cells by flicking with the index finger, place tubes on ice, and cover with aluminum foil to protect from light for all subsequent steps (see Note 11).

3. Incubate cells on ice for $30 \mathrm{~min}$, with gentle mixing every $10 \mathrm{~min}$ to prevent cells from settling at the bottom of the tube.

4. Wash cells by adding $1 \mathrm{~mL}$ of ice cold PBS to each tube and spinning for $5 \mathrm{~min}$ at $250 \mathrm{~g}$ at $4^{\circ} \mathrm{C}$. Carefully decant supernatant. Cells will remain as a pellet on the bottom of the tube.

5. Resuspend cells in the same initial volume of staining buffer and add secondary antibody as indicated in Table 14.1.

6. Incubate cells on ice for $30 \mathrm{~min}$, with gentle mixing as before.

7. Wash cells by adding $1 \mathrm{~mL}$ of ice cold PBS and centrifuging as before.

8. Prepare staining buffer containing propidium iodide (PI) by adding $1 \mu \mathrm{L}$ of the $10,000 \times$ PI stock to $10 \mathrm{~mL}$ of staining buffer and mixing well. The PI stock is made by dissolving $10 \mathrm{mg}$ of PI in $1 \mathrm{~mL}$ of PBS. Store for up to 1 month protected from light at $4{ }^{\circ} \mathrm{C}$.

9. Resuspend cells in the buffer indicated in Table 14.1 at their initial volumes

10. Set up the flow cytometer and ensure that excitation is available from both the $488 \mathrm{~nm}$ (for measurement of FSC, SSC, PE, and PI) and $633 \mathrm{~nm}$ (for measurement of APC) lasers and that the instrument is recording from detectors for all three fluorescent channels, typically FL2, FL3, and FL4 (see Note 12). 
11. Run the unstained control cells and adjust the voltage on each detector so that the cells are widely distributed but still all visible in a plot of FSC versus SSC, and so that cells are visible, but negative (i.e., $<10^{1}$ units of fluorescence), in the three fluorescence channels. The FSC and SSC detectors should be set to a linear scale, while all fluorescence channels should be set to logarithmic scales. A detailed flowchart for instrument setup is provided in Fig. 14.1A. Plots for unstained cells should appear similar to those in Fig. 14.1B, C. Create region R1 on the FSC versus SSC plot to use for excluding non-cell debris from further analysis and gate all subsequent plots on R1.

12. Beginning with the PE single color control, run each single stained sample, and adjust the compensation between channels to eliminate overlap in the fluorescence signal. Plots for single-stained controls should appear similar to those in Fig. 14.1D-F.

13. After adjusting the voltage and compensation for the unstained and single stained controls, create region R2 on the FSC versus PI plot to exclude PI positive, dead cells. Finally, define a gate which includes cells only in regions R1 and R2, and display these cells on a plot of PE ( $\alpha 6$ ) versus APC (CD34). Depending on the age of themouse from which the cells were isolated, one or two populations of bulge cells expressing high levels of CD34 should be visible (Fig. 14.1G and Fig. 14.2).

14. Create regions around the bulge cell populations for subsequent analysis and/or sorting.

15. Cells collected for culture can be sorted directly into micro-fuge tubes containing antibiotic-antimycotic supplemented E medium with no added calcium. To prevent cells from sticking to the sides of the collection tube, pre-coat the tube by filling it with 50\% chelated FBS in PBS and incubating at room temperature for $30 \mathrm{~min}$. Discard the coating solution before adding collection media. Once sorted cells have been collected, keep them on ice at all times, and place them in culture as soon as possible.

\subsection{Culture of FACS-Isolated Skin Epithelial Stem Cells}

1. At least 1 hour before plating sorted cells, plate mitomycin $C$ treated feeder cells growing in $\mathrm{F}$ medium in the desired culture vessel, typically a 24-well plate, and allow them to adhere. One confluent $10 \mathrm{~cm}$ plate of treated feeder cells typically provides enough cells to prepare an entire 24-well plate for co-culture.

2. Prepare $\mathrm{E}$ medium for cell culture by adding stock calcium to a final concentration of $0.3 \mathrm{mM}\left(500 \mu \mathrm{L}\right.$ of $0.06 \mathrm{M} \mathrm{CaCl}_{2}$ stock per $100 \mathrm{~mL}$ of E medium $)$ and adding antibiotic-antimycotic solution to a final $1 \times$ concentration $(1 \mathrm{~mL}$ of $100 \times$ stock solution per $100 \mathrm{~mL}$ of E medium).

3. Aspirate F medium from feeder cells and replace with pre-warmed calcium and antibiotic-antimycotic supplemented E medium.

4. Gently vortex tubes contained sorted bulge cells and spin for $5 \mathrm{~min}$ at $250 \mathrm{~g}$ at $4^{\circ} \mathrm{C}$ to pellet cells out of collection media. Carefully remove supernatant and resuspend cells in a small volume of E no calcium media, typically $100-200 \mu \mathrm{L}$ per $1.5 \mathrm{~mL}$ microfuge tube. Note that the pellet is often invisible.

5. Use the hemocytometer and trypan blue to count the number of viable cells in the suspension (see Note 13).

6. Plate $10^{3}-10^{4}$ viable bulge cells per single well in a 24 -well plate. 
7. Feed cells with fresh $\mathrm{E}$ medium supplemented with $0.3 \mathrm{mM}$ calcium every 3 days. Addition of antibiotic-antimycotic is not necessary if there is no evidence of contamination after 3 days. Colonies will begin to be visible by 7 days (Fig. 14.3) and will typically be ready for passaging by 14 days (see Note 14).

\subsection{Use of FACS Isolated Bulge Cells for Specific Applications}

1. BrdU Quantification: Measuring BrdU incorporation in the bulge cell populations by FACS is valuable for quantitative assessment of cell cycle kinetics in BrdU pulse or pulse-chase experiments. BrdU detection can easily be added to the $\alpha 6$-integrin/CD34 staining protocol using monoclonal antibodies directed against BrdU (available from BD Pharmingen and other sources) and established staining protocols $(11,12)$.

2. RNA Isolation: Bulge cells can be collected for subsequent RNA isolation by sorting cells directly into lysis buffer from any method appropriate for purifying RNA from small populations of cells. The lysis buffer should be chilled during collection to minimize RNA degradation, and care should be taken to collect only the recommended number of cells per volume of lysis buffer used.

3. Grafting: A wide variety of techniques exist for reconstituting skin by grafting mixtures of epidermal and dermal cells onto immunocompromised Nude mice. Although the number of bulge cells which can be isolated by FACS is often too small for direct grafting experiments, their numbers can easily be expanded by culturing for several passages $(7,13)$.

4. Viral Manipulation: Cultured epithelial cells can be successfully infected with several types of retroviruses as well as VSV-G pseudotyped HIV-derived lentiviruses (14, 15). Regardless of the system used, it is important to note that the high calcium concentration of the media used to collect the virus can cause epithelial cells to differentiate and cease proliferating. To avoid this, cells must be exposed to viral supernatant for only a limited period of time, or the virus must be either purified or concentrated from the supernatant.

\section{Notes}

1. Although the use of just $\alpha 6$-integrin and CD34 is sufficient to isolate distinct and substantially enriched populations of bulge cells by FACS, and may be sufficient for most applications, the addition of a transgenic fluorescent marker expressed exclusively in epithelial cells (such as K14-GFP) is needed to guarantee that $\alpha 6$ integrin ${ }^{+} / \mathrm{CD} 34^{\mathrm{High}}$ cells are derived from the bulge and do not represent contaminating cells from other non-epithelial tissues. GFP expressing cells are particularly useful for quick visualization in culture and for lineage marking in grafting experiments. If a flow cytometer with sufficient fluorescence channels is available, an antibody directed against $\beta 4$-integrin, which is specific for epithelial cells in the skin, can also be used in conjunction with $\alpha 6$ - integrin and CD34 to increase the purity of bulge cells.

2. Use plastic containers since all of these compounds adhere to glass.

3. $\alpha 6^{\mathrm{High}} \mathrm{CD} 34^{\mathrm{High}}$ bulge stem cells have also been grown successfully in culture media based on William's E medium (Gibco Invitrogen) and non-chelated FBS $(6,16)$. Media based on commercial base preparations specifically optimized for keratinocytes, such as KBM (Cambrex Bio Science) and DK-SFM (Gibco Invitrogen) can support the growth of bulk adult mouse keratinocytes and may also be suitable for bulge stem cells $(17,18)$. 
4. If desired, this protocol can be scaled down to produce a smaller amount of media. However, media can be conveniently stored at $20^{\circ} \mathrm{C}$ until needed and producing a larger batch of media allows for improved consistency across experiments.

5. When grown in DMEM with $10 \%$ FBS, 3 T3 cells grow with a doubling time of approximately $18 \mathrm{~h}$ in sparse culture and reach a saturation density of about 4 million cells per $100 \mathrm{~mm}$ plate. Cells can be maintained at this saturation density for several weeks, provided the media is changed twice weekly. In order to maintain this property of high contact inhibition, it is necessary to passage cells only at high dilutions, otherwise variants tend to be selected having reduced contact inhibition. It is also simple to make clonal isolates from 1:100,000 dilutions of confluent plates, selecting for clones with a high degree of contact inhibition. Once a good line of line of 3T3 cells has been derived, glycerol stocks should be made to allow for consistent propagation from a similar passage number over time.

6. If the medium is not red to red/orange in color, bubble compressed $\mathrm{CO}_{2}$ through the medium before attempting any $\mathrm{pH}$ adjustments. Usually no adjustment will be necessary.

7. It is essential to remove all of the fat attached to the dermis in order for trypsin to easily penetrate the tissue and dissociate cells. If the fat has been insufficiently removed, separation of the epidermal cells from the dermis will be difficult, and the yield of single cells will be very low. In the event that separation of the epidermis is difficult after overnight incubation at $4^{\circ} \mathrm{C}$, the skins can be additionally incubated at $37^{\circ} \mathrm{C}$ for 30 min prior to epidermal separation.

8. Use of chelated fetal bovine serum in staining buffer is essential because even trace amounts of calcium will cause cells to adhere to each other and form clumps. It is often easier to resuspend the cell pellet using a P1000 micropipette than a $10 \mathrm{~mL}$ pipette.

9. As an optional control for culture experiments, cells from this step may be placed directly in culture to assess initial cell viability before subjecting cells to staining and sorting.

10. The volumes listed are appropriate for staining cells isolated from the entire epidermis of two adult mice. However, the preparation can be easily scaled up or down in increments of $500 \mu \mathrm{L}$ per total yield of cells from one epidermis.

11. Multiple fluorophore combinations can be used as labels for $\alpha 6$-integrin and CD34, and this choice may be dictated by reagents already at hand or the capabilities of a particular flow cytometer. We routinely use the combination of PE and APC fluorophores because they are relatively photostable, provide a broad dynamic range and because this combination leaves the FL1 channel available for detecting GFP in cells isolated from transgenic mice or measuring BrdU incorporation via anti-BrdU antibodies directly coupled to FITC.

12. The proper setup and operation of flow cytometers are complex and beyond the scope of this chapter. For general background and theory of flow cytometry, a comprehensive reference should be consulted (11).

13. Although the flow cytometer will provide a count of sorted cells, this number often substantially exceeds the cell count determined by trypan blue exclusion because not all cells survive the collection process intact.

14. Cultured bulge cells are most easily passaged by first removing feeder cells before trypsinization to collect bulge cells. After aspirating the media, wash the well twice with PBS. Use a P1000 pipettor to repeatedly direct a gentle stream of PBS 
perpendicular to the surface of the dish. The feeder cells, which are less adherent than the epithelial cells, will be dislodged from the surface of the tissue culture dish. Colonies of bulge cells will now be clearly visible. Wash away floating feeders before trypsinizing epithelial cells and passaging onto fresh feeder cells.

\section{References}

1. Cotsarelis G, Sun TT, Lavker RM. Label-retaining cells reside in the bulge area of pilosebaceous unit: implications for follicular stem cells, hair cycle, and skin carcinogenesis. Cell 1990;61(7):1329-1337. [PubMed: 2364430]

2. Morris RJ, Potten CS. Highly persistent label-retaining cells in the hair follicles of mice and their fate following induction of anagen. J Invest Dermatol 1999;112(4):470-475. [PubMed: 10201531]

3. Taylor G, et al. Involvement of follicular stem cells in forming not only the follicle but also the epidermis. Cell 2000;102(4):451-461. [PubMed: 10966107]

4. Tumbar T, et al. Defining the epithelial stem cell niche in skin. Science 2004;303(5656):359-363. [PubMed: 14671312]

5. Morris RJ, et al. Capturing and profiling adult hair follicle stem cells. Nat Biotechnol 2004;22(4):411417. [PubMed: 15024388]

6. Trempus CS, et al. Enrichment for living murine keratinocytes from the hair follicle bulge with the cell surface marker CD34. J Invest Dermatol 2003;120(4):501-511. [PubMed: 12648211]

7. Blanpain C, et al. Self-renewal, multipotency, and the existence of two cell populations within an epithelial stem cell niche. Cell 2004;118(5):635-648. [PubMed: 15339667]

8. Rheinwald JG, Green H. Epidermal growth factor and the multiplication of cultured human epidermal keratinocytes. Nature 1977;265(5593):421-424. [PubMed: 299924]

9. Rheinwald JG, Green H. Serial cultivation of strains of human epidermal keratinocytes: the formation of keratinizing colonies from single cells. Cell 1975;6(3):331-343. [PubMed: 1052771]

10. Todaro GJ, Green H. Quantitative studies of the growth of mouse embryo cells in culture and their development into established lines. J Cell Biol 1963;17:299-313. [PubMed: 13985244]

11. Shapiro, HM. Practical flow cytometry. Vol. 4 ed.. Wiley-Liss; 2003. p. 736

12. Gratzner HG, Leif RC. An immunofluorescence method for monitoring DNA synthesis by flow cytometry. Cytometry 1981;1(6):385-393. [PubMed: 7023886]

13. Weinberg WC, et al. Reconstitution of hair follicle development in vivo: determination of follicle formation, hair growth, and hair quality by dermal cells. J Invest Dermatol 1993;100(3):229-236. [PubMed: 8440892]

14. Kuhn U, et al. In vivo assessment of gene delivery to keratinocytes by lentiviral vectors. J Virol 2002;76(3):1496-1504. [PubMed: 11773422]

15. Garlick JA, et al. Retrovirus-mediated transduction of cultured epidermal keratinocytes. J Invest Dermatol 1991;97(5):824-829. [PubMed: 1919048]

16. Wu WY, Morris RJ. Method for the harvest and assay of in vitro clonogenic keratinocytes stem cells from mice. Methods Mol Biol 2005;289:79-86. [PubMed: 15502172]

17. Redvers RP, Kaur P. Serial cultivation of primary adult murine keratinocytes. Methods Mol Biol 2005;289:15-22. [PubMed: 15502165]

18. Yano S, Okochi H. Long-term culture of adult murine epidermal keratinocytes. Br J Dermatol 2005;153(6):1101-1104. [PubMed: 16307643] 
A
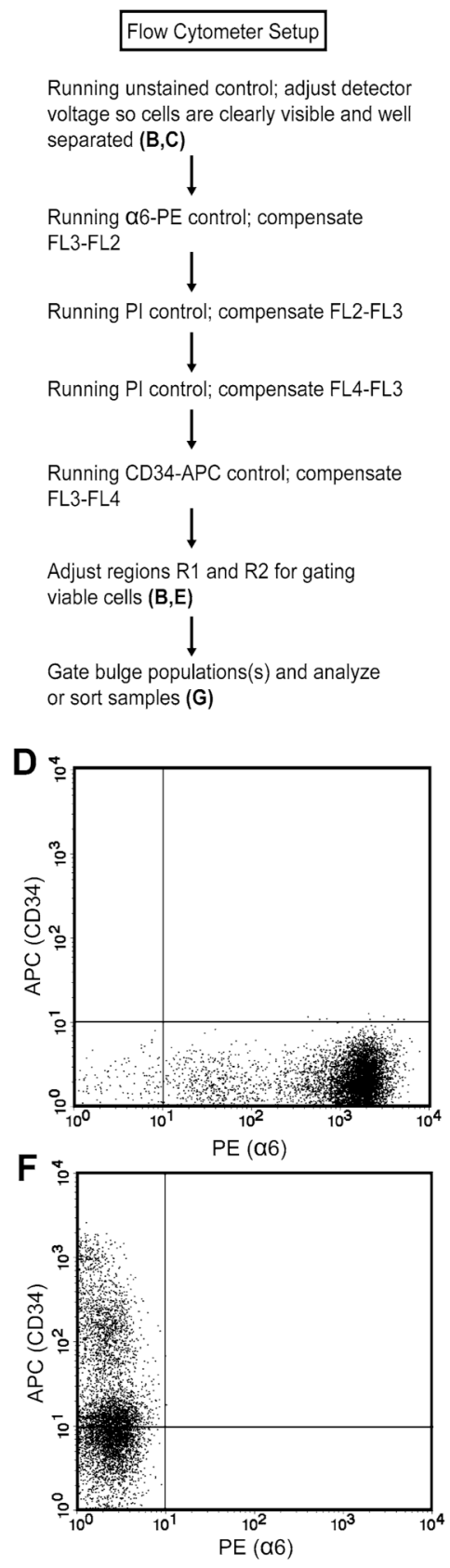
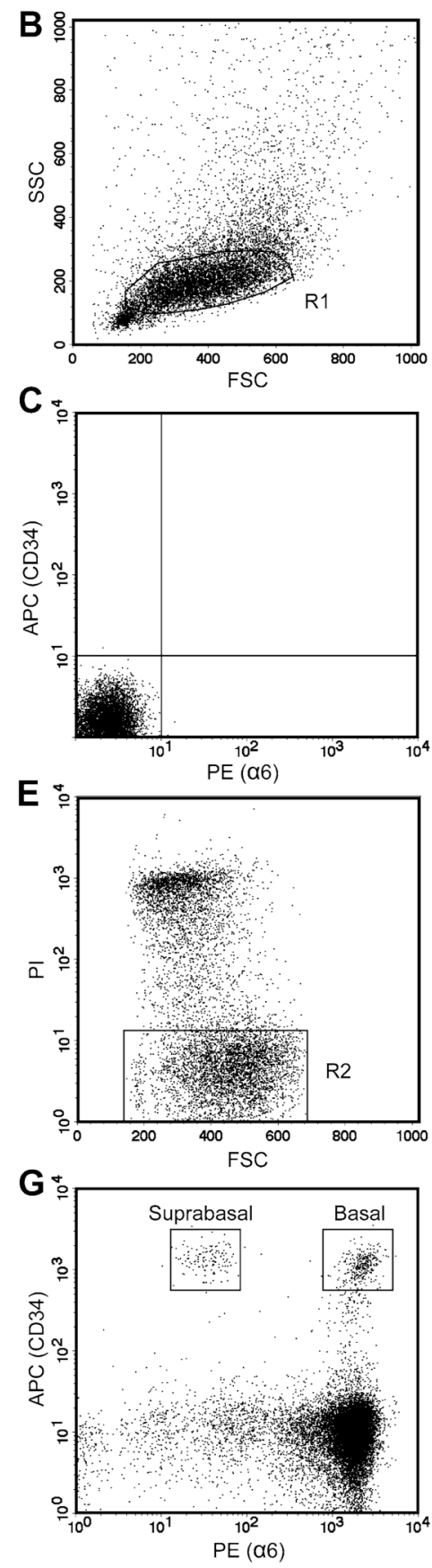

Fig. 14.1.

Identification of hair follicle bulge cells by FACS. Skin epithelial cells from 7-week-old mice were enzymatically isolated to produce a single cell suspension which was stained for $\alpha 6$ integrin and CD34. (A) Protocol used for setting detector voltage and compensation on the flow cytometer. (B) Forward (FSC) versus side scatter (SSC) plot of unstained cells determines the location of the R1 gate, used for excluding debris from all subsequent plots. (C) Unstained cells are visible on the plot of FL2 (PE) and FL4 (APC), but remain within the double negative quadrant. (D,F) Singly stained $\alpha 6-\mathrm{PE}$ and CD34-APC control cells distribute along the expected axes. (E) Propidium iodide (PI) staining is used to identify viable cells, shown here in region R2. (G) Double staining for CD34-APC and $\alpha 6-\mathrm{PE}$, along with gating on regions R1 
and R2, demonstrates two distinct bulge cell populations- the suprabasal $\alpha 6^{\text {Low }} \mathrm{CD} 34^{\mathrm{High}}$ and basal $\alpha 6^{\mathrm{High}} \mathrm{CD} 34^{\mathrm{High}}$ population. 
A

Telogen I (d20)
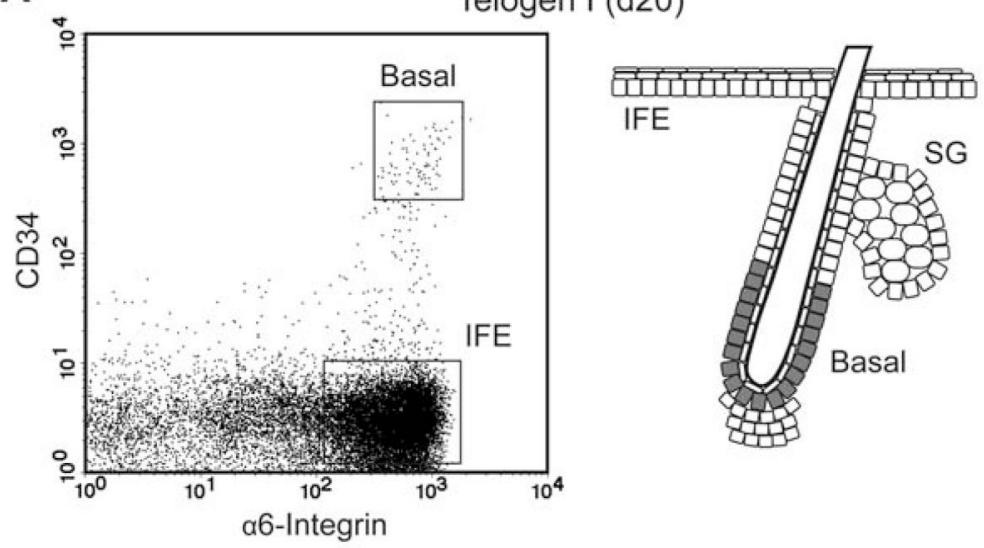

B

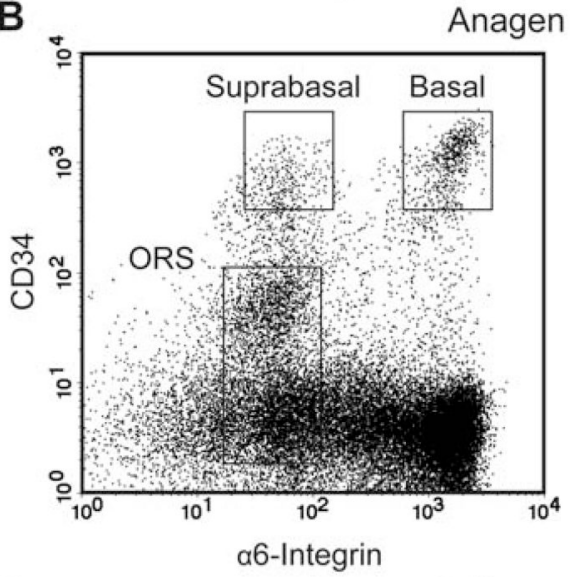

(d28)
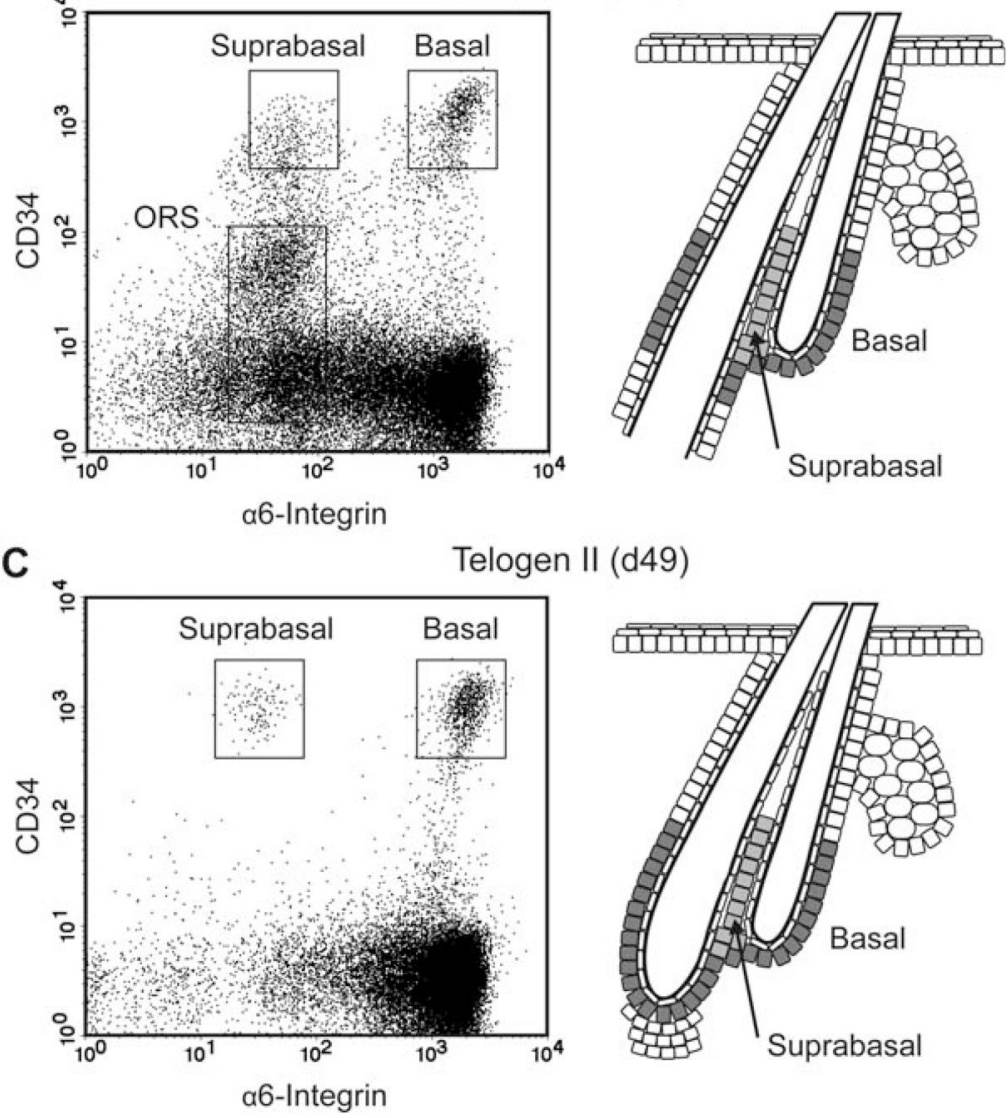

Fig. 14.2.

Expression levels of $\alpha 6$-integrin distinguish two populations of $\mathrm{CD} 34^{\mathrm{High}}$ bulge cells. (A) CD34 is specifically enriched in the bulge region of the hair follicle beginning at the first telogen stage of the hair cycle, approximately day 20 . A single layer of uniformly $\alpha 6^{\mathrm{High}}$ basal bulge cells (dark grey) surround the lower portion of the club hair, below the sebaceous gland (SG). Basal cells of the interfollicular epidermis (IFE) and upper hair follicle are present as a $\alpha 6^{\mathrm{High}} \mathrm{CD} 34^{-}$population. (B) During the next anagen stage of the hair cycle, the growth of a second hair shaft creates a new population of $\alpha 6^{\mathrm{Low}} \mathrm{CD} 34^{\mathrm{High}}$ suprabasal bulge cells (light grey). During this stage, cells from the lower, cycling portion of the outer root sheath (ORS) are also visible as a population of $\alpha 6^{\text {Low }} \mathrm{CD} 34^{\mathrm{Low} /-}$ cells. (C) During the second telogen stage 
of the hair cycle, both the $\alpha 6^{\mathrm{High}} \mathrm{CD} 34^{\mathrm{High}}$ and $\alpha 6^{\mathrm{Low}} \mathrm{CD} 34^{\mathrm{High}}$ populations are distinct, and the cycling portion of the outer root sheath is absent. 

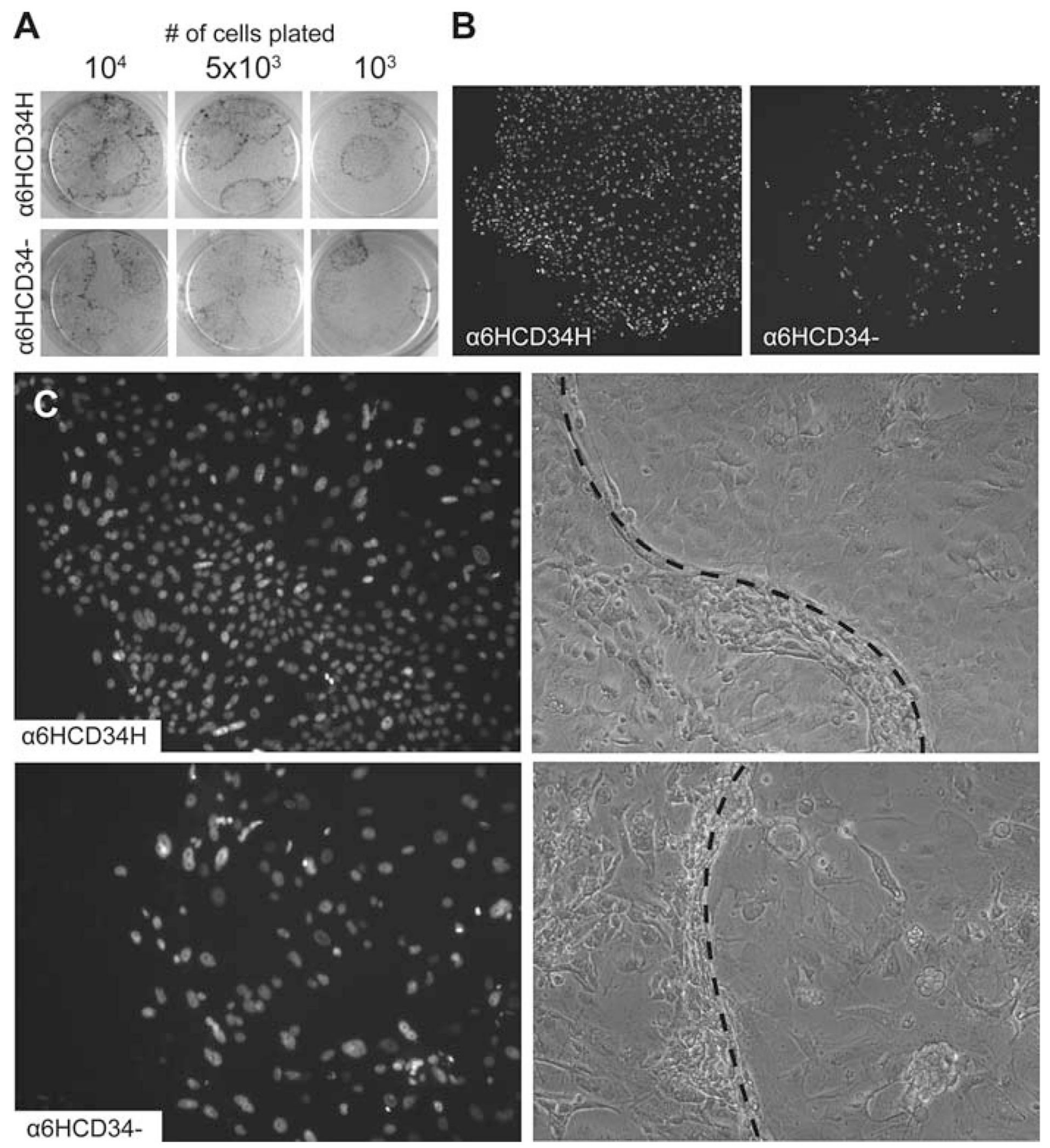

Fig. 14.3.

Bulge cells display distinct growth properties when placed in culture. The $\alpha 6^{\mathrm{High}} \mathrm{CD} 34^{\mathrm{High}}$ bulge cells and $\alpha 6^{\mathrm{High}} \mathrm{CD} 34^{-}$epidermal cells were isolated by FACS from mice expressing a GFP-tagged histone $\mathrm{H} 2 \mathrm{~B}$ under the control of a keratin 14 promoter. (A) Rhodamine B staining of cultured cells shows that although both cell populations have similar colony forming efficiencies, colonies derived from bulge cells tend to be larger and more regularly shaped. (B) GFP fluorescence demonstrates that $\alpha 6^{\mathrm{High}} \mathrm{CD} 34^{\mathrm{High}}$ cells give rise to densely packed colonies with regular borders, while $\alpha 6^{\mathrm{High}} \mathrm{CD} 34^{-}$cells generate sparser colonies with a more irregular appearance. (C) GFP fluorescence (left) and phase contrast images (right) show that colonies derived from $\alpha 6^{\mathrm{High}} \mathrm{CD} 34^{\text {High }}$ cells consist largely of small, undifferentiated cells 
with a uniform morphology, while $\alpha 6^{\mathrm{High}} \mathrm{CD} 34^{-}$colonies contain a mix of larger cells with more variable morphology. Note that colonies begin growing underneath the feeder cell layer, and feeder cells are gradually pushed aside as the colony expands in size. Dotted lines indicate the approximate boundary between feeder cells $(l e f t)$ and epidermal cells $(r i g h t)$. 
흘 姜

ن

氙 음

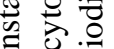

$\exists$

츨

\& $0 . \overline{0}$

此

으을

旸

ขํㅠ ๘

它

ర ల్ల

क ष

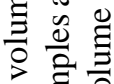

䟢

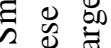

$\dot{\oplus} \frac{\pi}{\pi}$

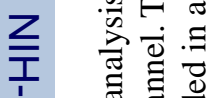

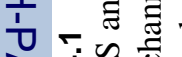

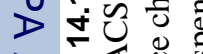

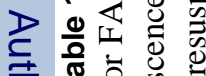

客

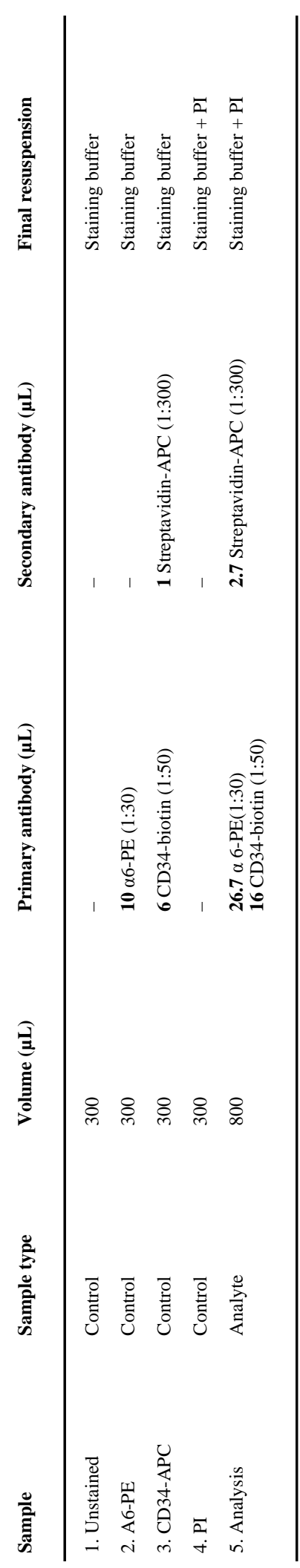

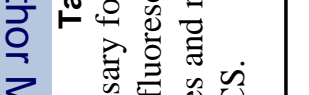

》

क⿺

穿宇 专

\#正

$\stackrel{2}{*}=$

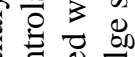

ส

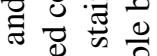

을.

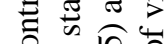

Z 它公告范

त

录疍

节它曾

言 